\title{
Transforming Mount Airy into Mayberry \\ Film-Induced Tourism as Place-Making
}

\author{
DEREK H. ALDERMAN \\ University of Tennessee
}

STEFANIE K. BENJAMIN

University of South Carolina

PAIGE P. SCHNEIDER

East Carolina University

Film-induced tourism is increasingly popular in the United States and globally. Scholars have tended to emphasize the effect of movies and television in forming the image of tourist destinations and thus influencing traveler motivation and experience. In this article, we shift discussion of film tourism beyond simply place image formation to consider it in the broader context of place-making. Such a perspective offers a fuller recognition of the material, social, and symbolic effects and practices that underlie the construction of film tourism destinations and their place identities as well as the ideologies, power relations and inequalities that become inscribed into the place transformation process. We focus on film tourism in Mount Airy, North Carolina, the birth place of television actor Andy Griffith, and delve into the remaking of his home town into a simulated version of Mayberry. Griffith popularized the fictional town of Mayberry in his 1960 s television series and it continues to resonate with fans of the show. Mount Airy is marketed to visitors as the "real life Mayberry," despite what Griffith has said to the contrary, and the city hosts an annual Mayberry Days Festival, which we visited and photographed in 2010. A preliminary interpretation is offered of the landscape changes, bodily performances, and social tensions and contradictions associated with the remaking of Mount Airy into Mayberry. We also as- sert the need to address the social responsibility and sustainability of this transformation, particularly in light of the competing senses of place in Mount Airy, generational and racial changes in the travel market, and the way in which African Americans are potentially marginalized in this conflation of the "real" and the "reel."

El turismo inducido por el cine es cada vez más popular en los Estados Unidos y el mundo. Los académicos han tendido a enfatizar el efecto de las películas y la televisión en la formación de la imagen de los destinos turísticos, los cuales influyen en la motivación y la experiencia de viajero. En este artículo, movemos la discusión sobre el turismo de cine más allá de simplemente la formación de imágenes de lugares para considerar en el contexto más amplio la formación de lugares. Tal perspectiva ofrece un reconocimiento más completo de los efectos y prácticas materiales, sociales, y simbólicas que subyace la construcción de los destinos turísticos de cine y sus identidades de lugar, así como las ideologías, las relaciones de poder y las desigualdades que se inscriben en el proceso de transformación de lugares. Nos centramos en el turismo de cine en Mount Airy, Carolina del Norte, el lugar de nacimiento del actor de televisión Andy Griffith, y profundizamos en la reconstrucción de su ciudad natal en una versión simulada de May- 
berry. Griffith popularizó la ciudad ficticia de Mayberry en su serie de televisión de 1960, quién continua resonando entre los fans de la serie. Mount Airy se comercializa a los visitantes como "el Mayberry de la vida real," a pesar de que Griffith ha dicho lo contrario, y la ciudad organiza anualmente el Festival de los Tiempos de Mayberry, el cual hemos visitado y fotografiado en 2010. Una interpretación preliminar se ofrece de los cambios en el paisaje, comportamientos corporales, y las tensiones y contradicciones sociales asociadas con la reconstrucción de Mount Airy en Mayberry. También afirmamos la necesidad de abordar la responsabilidad social y la sostenibilidad de esta transformación, especialmente en términos de los sentidos de lugar en competencia en Mount Airy, cambios generacionales y raciales en el mercado de viajes, y la forma en que los afroamericanos son potencialmente marginados en esta fusión de lo "real"y el "guión."

KEY WORDS: film-induced tourism, Mayberry, Mount Airy, place-making, sustainability, African American

PALABRAS CLAVES: turismo inducido por el cine, Mayberry, Mount Airy, construcción de lugar, sostenibilidad, afro-americanos

\section{INTRODUCTION}

Geographers have not studied filminduced tourism to a great extent. This is surprising given the iconic role played by place in movie-making and the considerable amount of scholarship that has investigated the relationship between geography and the mass media (e.g., Burgess and Gold 1985; Zonn 1990; Aitken and Zonn 1994; Cresswell and Dixon 2002; Adams 2009). Meanwhile, a growing number of people are traveling to destinations to recapture the distinctive sense of place por- trayed on screen, and film-induced tourism is increasingly promoted in the United States and globally as a marketing and economic development tool (Roesch 2009; Beeton 2010; Kim 2010). As Edensor (2009, p 311) observed, "there are now a plethora of destinations which have become associated with mediated imagery in film and television, with celebrities, cinematic scenes, and landscapes."

Film-induced tourism can take at least three forms (Riley et al. 1998; Butler 2011). The first involves people visiting places where film and television productions were shot or captured on film. For example, some avid fans of the Lord of the Rings trilogy travel to New Zealand as Tolkien tourists and seek out sites used as backdrops in those films (Carl et al. 2007). The second form of film tourism involves people visiting places represented in the plot or storyline of media productions, although the production may or may not have been shot there. The small town of Forks, Washington is the setting for the Twilight movie franchise about a young-adult vampire romance. Although no actual filming took place in Forks, this fact has not stopped thousands of tourists from visiting or townspeople from capitalizing on the newly found fame (Garofoli 2010). The third form of tourism involves people traveling to places that simulate or mimic film and television representations and allow tourists to reexperience those images vicariously. Universal Studios in Orlando, Florida, for example, is a large theme park with rides, shows, and other experiences that allow visitors to feel as if they are on the set of several popular television shows and feature films. It is worth pointing out that a certain measure of simulation can be found at most film tourism destinations. For example, in the case of 
Twilight's town of Forks and those portions of New Zealand related to Lord of the Rings, local business owners have created special film-themed attractions and tours, and it is not uncommon to see some tourists dressing up as movie characters or re-enacting film scenes at these destinations.

Much of the existing research on filminduced tourism has measured the impact of media productions on people's perceptions of places while also determining the nature and extent to which these images shape the travel decisions and experiences of tourists (e.g., Young and Young 2008; Hahm and Wang 2011; Hudson et al. 2011). Underlying many of these studies is the belief that film tourism can significantly benefit local economies, increase publicity and recognition of destinations, expand infrastructure, and revitalize communities. Another avenue of research, led by scholars such as Beeton (2005; 2006b), has advocated for a more critical appraisal of the drawbacks as well as advantages of filminduced tourism within communities. The popularity of film tourism can compromise the social and environmental quality of life of destinations, especially if local communities are unprepared for the tourist influx. In addition, ambiguity and tension can arise from ensuring that the "real" or actual place lives up to the "reel" or imagined place as created through film (Beeton 2001). Of particular concern to us is how the marketing and development of film tourism can potentially marginalize other types of travelers and some members of the resident community. Few studies have addressed the social equity of film-induced tourism, particularly in terms of its impact on sense of place and belonging.

Whether scholars have touted benefits or problems, they have tended to charac- terize film tourism as a tool in destination marketing and place image formation and alteration (Hudson and Ritchie 2006; O'Connor et al. 2010). They emphasize "the power of film on creating awareness, enhancing images, changing images, and igniting a motivation to visit a place" (Hahm and Wang 2011, p 176). Yet, the impact of media and film tourism on place is not simply perceptual. Missing from many studies is a wider discussion of the involvement of film tourism in the social and material production of place and place identity (but see Jewell and McKinnon 2008). Indeed, as geographers Hanna and Del Casino have argued, place representation and embodied social and spatial practices are not binary opposites but mutually constitutive. According to them, representation can be conceived of as work and as part of the material process by which tourist places are made (Hanna et al. 2004). By the same virtue, material changes to places do not happen outside the context of how we perceive, think about, and talk about place. Places, according to Davis (2005, p 610), are "discursive-material formations," in which the representation of place enables and "legitimizes the performance of certain activities in those places as well as directs the social practices that actively shape the landscape." Rosati (2007) has contended that the study of media geographies must move beyond simply interpreting images and representations to consider the built environment and social contexts that make the power of these images realized and tangible. Although not in the context of film-induced tourism, Bandyopadhyay and Nascimento (2010) argued that tourism representations affect how the people and places of destinations are consumed by tourists. According to them, even 
fantasies and myths in marketing images can strongly shape tourist expectations and thus have real and denigrating repercussions for marginalized populations.

In this article, we shift discussion of film tourism beyond simply place image formation to consider it in the broader context of place-making. Such a perspective offers a fuller recognition of the material, social, and symbolic effects and practices that underlie construction of film tourism destinations and their place identities as well as the ideologies, power relations, and inequalities that become inscribed into the place transformation process. Perhaps no community better illustrates the significant place transformations that accompany film tourism than Mount Airy, North Carolina, where promoters have actively remade portions of the town into a simulated version of Mayberry. Mount Airy is the birth place and boyhood home of television actor Andy Griffith, who popularized the fictional town of Mayberry in his 1960s television series. The television show created a place ideal that still greatly resonates with portions of the viewing public as a form of nostalgia. Mount Airy is marketed to visitors as the "real life Mayberry," despite what Griffith has said to the contrary, and the city hosts an annual Mayberry Days Festival, which we visited in 2010.

Using participant observation and photography at the festival, archival newspaper research, and discussions with residents and visitors, we offer a preliminary interpretation of the landscape changes, bodily performances, and social tensions and contradictions that underlie the remaking of Mount Airy into Mayberry. As we suggest, identifying Mount Airy as Mayberry is not simply a marketing tool, but represents a fundamental reconstruc- tion of place that, while creating entertainment and a sense of belonging for some, can also be interpreted and experienced differently, if not negatively, by others. We assert the need to address the social responsibility and sustainability of this transformation, particularly in light of competing senses of place in Mount Airy, generational and racial changes in the travel market, and the way in which African Americans are potentially marginalized in this conflation of the "real" and the "reel."

Finding the promotion of a place identity in Mount Airy that seemingly disenfranchises African Americans is not necessarily a unique occurrence, especially in the American South. Indeed, the larger trajectory of our work inside and outside of Mount Airy is to conduct a critique of how southern hospitality is constructed in socially selective ways. Other aspects of the region's tourism industry-from plantation heritage tours to welcome center brochures-make African Americans invisible and presumably unimportant (e.g., Alderman and Modlin 2008; Alderman and Modlin forthcoming). The research reported here contributes to a new initiative called RESET (Race, Ethnicity, and Social Equity in Tourism), which recognizes the highly discriminatory history of travel in the region and the continuing obstacles to full inclusion of African Americans within the southern tourism experience.

\section{MOUNT AIRY AS SIMULATED MAYBERRY}

Mount Airy, North Carolina (2010 population: 10,388) is located in Surry County at the foothills of the Blue Ridge Mountains near the Virginia border. Not far from 
major flows of travelers along the Blue Ridge Parkway and reeling from significant job losses, Mount Airy has aggressively worked since the 1980s to develop tourism that capitalizes on the popularity of the television series The Andy Griffith Show (1960-1968) and the program's imaginary hamlet of Mayberry (Janiskee and Drews 1998). The Andy Griffith Show was never filmed in Mount Airy (it was shot in California) and the town was never mentioned by name on television. Nevertheless, Mount Airy identifies itself as Mayberry, producing a tourist landscape designed to reference, and at times recreate, people, places, and experiences from the show. While Mount Airy has other viable development avenues, including non-Andy Griffith tourism, the town's close identification with Mayberry has received the most national and international attention (e.g., Sack 1997; Becker 2002; Bly 2010).

For those unfamiliar with The Andy Griffith Show, Mayberry is television's quintessential utopian community, where social cooperation, egalitarianism, and good will always win out over conflict, elitism, and self-interest. Townspeople know and help each other, regardless of social position, personal failing, or eccentricity. And Mayberry is filled with its share of eccentrics-such as Otis Campbell (played by Hal Smith), the town drunk who voluntarily locks himself in the city jail to sleep off a bender; Barney Fife (Don Knotts), the hyper-vigilant yet bumbling deputy sheriff who often discharges his gun by accident and is only allowed to have a single bullet that he carries in his front shirt pocket; and Floyd Lawson (Howard McNear), the absentminded barber who cannot cut sideburns evenly and inadvertently allows a bookie to set up business in the barber shop. Watching Andy Griffith, according to Sanes (2010), "vicariously places us in a benevolent social world in which human foibles are forgivable and ... where even foolishness can feel at home."

When The Andy Griffith Show originally aired, Mayberry was purposely represented as a world away from the major challenges of the time, such as the Vietnam War, the Civil Rights Movement, student demonstrations, assassinations, and anxiety over nuclear war (Vaughn 2004). Problems do exist in Mayberry, but they tend to be small and easily dealt with. The show's feature character, Sheriff Andy Taylor (played by Andy Griffith), solves most of these problems using his wit and folksy wisdom. The show, despite its title, is not just about Andy Griffith. Rather, it is about life in a small southern town that is as wholesome as it is nutty. As Vaughn (2004, p 420) observed, "In virtually every episode [of The Andy Griffith Show], there are instances of at least one character being sensitive to someone else's needs, problems, and feelings." It is a yearning for the idea of a simpler and kinder time and place that makes Mayberry popular among fans and partly explains their motivations for visiting Mount Airy. Brown (1997, p 187) noted this longing for a lost past among Mount Airy visitors. A woman he interviewed said: "The spirit of Mayberry is here. You can talk to anybody and they're real nice and friendly. You can talk to people you don't even know and you don't have to worry about anything."

The Andy Griffith Show has never left the air in the over fifty years since its premiere, thanks in large part to syndication and cable channels such as WGN, TBS, and TV Land. Among the many classic television shows re-broadcast on TV Land, 
Andy Griffith is "among its top three mostwatched . . . programs, drawing 47 percent more viewers than the network average" for all shows (Curtis 2010, p 48). According to the fan web site, "A Mayberry State of Mind," there are over 1300 chapters of The Andy Griffith Show Rerun Watchers Club inside and outside the United States. Important to understanding the avid Andy Griffith Show fan is realizing the important role that the production and consumption of place plays in their emotional re-creation of "A Mayberry State of Mind." Marsha and Dave Scheuermann, for example, converted their house near Clear Lake, Wisconsin into an exact replica of the Andy Taylor home as seen on the television series-right down to the dining room plates and pictures on the walls. But this meticulousness is not just for the Scheuermanns-it is also for other fans. The Scheuermann home is a bed and breakfast (called The Taylor Home Inn) and guests are greeted by a "Welcome to Mayberry" sign on the front door (Imrie 2006).

Recognizing the profitability of providing a gathering place for die-hard fans to remember The Andy Griffith Show, the Surry County Arts Council hosted the first Mayberry Days Festival in 1990. By 1995, the festival hosted over 10,000 people annually, offering a mixture of "typical activities of a family-style street festival with a variety of attractions oriented to Andy Griffith Show fans" (Janiskee and Drews 1998, p 162). Festival goers can purchase television memorabilia, meet surviving stars from the show, learn about Andy Griffith's life story, and socialize with other fans. The downtown, with its small town look, reinforces the Mayberry image and hosts many of the festival activities and
Andy Griffith Show-themed businesses. Although Mount Airy hosts television-inspired visitors year round, the Mayberry Days Festival, held every September, is perhaps the most compelling time to observe and interpret the place identity transformation process.

\section{THE TENSION BETWEEN}

REAL AND REEL

Simulated film tourism as found in Mount Airy is especially interesting from a geographic perspective because of the manner in which places are being (re)constructed to serve as a "stand-in" for the actual media image, although the representation cannot ever be fully reproduced as seen on screen. As film-induced tourism illustrates in general and in Mount Airy in particular, the distinction between the "real" and the "reel" is increasingly blurred and conflated in today's world, where media representations heavily shape social life on the ground (Lukinbeal 2004). Perhaps the most forceful statement of how "simulations have come to dominate contemporary society and have produced a new kind of hyper-real social order" came from French theorist, Jean Baudrillard (Kellner 1988, p 243). The reproduction of the idealized television community of Mayberry in Mount Airy epitomizes Baudrillard's simulacra-the making of a copy of a copy for which there is no original (Brown 1997).

While it is unhelpful to draw a strict distinction between the real and the reel in today's media-based society, it is worth thinking about this distinction in relational terms (Dixon and Grimes 2004) and understanding how people construct, control, and even debate the blurring of real 
and reel places. Mount Airy promoters consistently claim that their town was the inspiration for Mayberry. They note, for example, how Andy Griffith incorporated elements of North Carolina and the local area into the show's storyline, such as the cities of Raleigh, Charlotte, Siler City, Bannertown, Mount Pilot (a reversal of the nearby Pilot Mountain), and Snappy Lunch (a diner in Mount Airy where Griffith ate as a child). Yet, Griffith has denied on a number of occasions that Mayberry was based, in any substantive way, on his hometown (Archive of American Television 1998). According to him, Mayberry was a composite of several small southern towns. The name Mayberry probably comes from a town in southern Virginia where Griffith's mother was born (Kutzer 2001). On a 2002 reunion show that aired on CBS, Andy Griffith contended: "Mayberry is not found on any map of the Carolinas. . . . Real towns have real problems that must be dealt with. All of Mayberry's problems are solved in a half hour" (Vaughn 2004, p 416-417). That same year, Griffith returned to Mount Airy for the dedication of a state highway in his honor. According to the Associated Press, which covered the dedication ceremony, Griffith admitted to those in attendance that Mayberry was modeled after Mount Airy (Nowell 2002, p A1). The actor's words at the ceremony were diplomatic but ambiguous on the matter: "Some people say that I patterned Mayberry after Mount Airy. Sure seems like it, doesn't it?"

The mythical nature of Mayberry has not stopped fans from treating the television community as if it really existed and holding up its way of life as a moral guide (Dickson 2004). Some fans go so far as to suggest that America has lost touch with the conservative social values that run throughout the storylines of The Andy Griffith Show and that finding one's "way back to Mayberry" can provide "real lessons" for everyday life (Fann 2001, p 1). It can be argued that some film-induced tourism is based on a form of "imagined nostalgia" (Jewell and McKinnon 2008) and Mount Airy tourism promoters have tapped into the public's nostalgic longing for the ideals symbolized in the 1960s television show. In doing so, Mount Airy actively equates itself as Mayberry, to the extent that the town has a website address that reads visitmayberry.com. As DeLyser (2003) found in studying the impact of Helen Hunt Jackson's novel, Ramona Memories, in California, to dismiss associations with fictional place images as simply a false past neglects to consider how these images become part of the public memory of a place and how they are made real socially and spatially. We are interested in the process by which the "reel" Mayberry is made "real" within Mount Airy and how this remaking of place and place identity impacts the North Carolina community.

There is certainly money to be made in blurring the line between the real and the reel in Mount Airy. Surry County Arts Council estimates that the local economic impact of the Mayberry Days festival is over five million dollars annually. The organization places great emphasis on delivering what tourists expect from a "real life Mayberry." When recruiting festival sponsors in 2010, the Arts Council was careful to point out that it "ONLY seeks sponsors that fit with the image and values that are portrayed on The Andy Griffith Show" (emphasis in original, Surry County Arts Council 2010). Research suggests that film tourist satisfaction is tied to maintain- 
ing a high degree of simulation through landscapes. In other words, "tourists' expectations were not met" when "it seemed that the 'real' landscapes did not resemble closely enough their film counterparts" (Carl et al. 2007, p 60). Yet, this simulation can lead to ambiguity over place identity and thus has important spatial and social repercussions (Hanna 1996). The remaking of Mount Airy into Mayberry can have a significant impact on how the North Carolina community looks materially and functions socially as well as what it means to people-not only visitors, but also residents. While many visitors and some locals view and celebrate Mount Airy and Mayberry as one in the same, others are less excited about this association and want to draw a firmer distinction, especially since it has a major bearing on their sense of place and belonging.

\section{SENSE OF PLACE AND}

\section{SUSTAINABILITY OF TOURISM}

The larger context of our work in Mount Airy is about exploring the social sustainability of film-induced tourism. Sustainability is often discussed in the context of promoting "green" or environmentally conscientious tourism practices. Yet, the concept is also concerned with social dimensions of tourism and minimizing the inequalities and tensions that have traditionally characterized the tourism industry, although Bramwell and Lane (2008, p 2) have noted the limited amount of research on these issues (but see Cole and Morgan 2010). A sustainable approach requires the tourism industry engage in socially responsible development, which addresses the varying attitudes and needs of local residents rather than just tourists as well as the differential and sometimes negative impact tourism can have on groups within host communities. A promotional remaking of place-however popular and economically viable it may be for some groups-can just as easily marginalize the cultural identities and livelihoods of other groups, especially those with a history of limited social power or say in the community. Although sustainability is open to a multitude of different definitions and interpretations, some advocates point out that sustainable tourism planning can and should bring historically divided groups together, address ingrained racial disparities, and facilitate minority empowerment and civil rights (e.g., Barton and Leonard 2010).

Understanding how social power relations work in a community, according to Beeton (2006a, p 81), "is crucial to developing a sustainable tourism industry." Especially important to geographers is the role that sense of place plays in these power relations. Sense of place is not monolithic in nature. As Johnson and her colleagues (2009, p 2) observed, "understanding sense of place can be a daunting task due to the need to document the range of views within a given community. . . . there can be multiple interpretations of place at a point in time and across time." There are multiple and potentially contradictory interpretations and experiences of place because people have different social and economic positions, histories, and interests within communities. Sustainable tourism is sensitive to the impact of tourism on people's identification with place. Sense of place affects one's sense of belonging within a destination, which can impact local support for tourism as well as participation in the wider cultural life of 
communities. Belonging, according to Antonsich (2010), is related to the discourses and practices of socio-spatial inclusion and exclusion, a means of defining membership to a group and ownership of a place. In principle, sustainable tourism should enhance, rather than degrade, the attachment that residents feel for their communities (Kerstetter and Bricker 2009).

Local people connect with the Mayberry place identity in different ways. For some, it is a source of community pride. When Mount Airy was selected as a finalist in the 2011 Rand McNally and USA Today contest for the "friendliest town in America," the online public was allowed to vote and post review comments. Several of the comments, many of them supplied by residents, perpetuated the identification of Mount Airy as Mayberry. For instance, one reviewer posted: "Its like Mayberry from the show, people smile and say Hi to everyone." Another wrote: "Our small town of Mayberry is very similar to the Andy Griffith show" (Best of the Road 2011).

Conspicuous, however, was the large number of online comments from locals who did not mention Mayberry at all. They cited other things that made Mount Airy attractive as a community. To this point, one reviewer posted: "Of course, everyone knows us as "Mayberry" since Andy Griffith was born here, but it is SO much more than that!" (Best of the Road 2011). The previous comment suggests that the Mayberry-related place identity runs the risk of excluding or de-emphasizing alternative place attachments. As of late, tourism officials in Mount Airy and Surry County have engaged in debates about how much marketing emphasis to put on the fictional Mayberry and whether the image overshadows other facets of the area. Indeed, there are ongoing efforts by promoters to bring greater tourist attention to Mount Airy's wineries, granite quarry, musical heritage, outdoor recreational opportunities, and other festivals (Mitchell 2011). The Autumn Leaves Festival, held since the 1960s, generates almost 8.5 million dollars annually in economic impact and attracts 200,000 visitors (Byrd 2008). Our informal discussions with some Mount Airy residents indicate a preference for the Autumn Leaves Festival because it is supposedly more authentic and showcases more local artists.

Our conversations with Mount Airy residents also expose the question of what place (if any) African American locals have in a simulated Mayberry. There are just a handful of instances in which black actors appeared in The Andy Griffith Show, but they occupy the distant and speechless background of scenes. The lone exception to this pattern in 249 episodes was the African American character, Flip Conroy (played by Rockne Tarkington), an ex-NFL star who volunteers to coach a boys football team that included Andy Taylor's son, Opie (played by Ron Howard). In hindsight, Andy Griffith has said he regrets his and the producers' decision to exclude African Americans, but explains that black actors at the time did not want to be portrayed in servant roles and "there is no way in some small town in the South that white people were going to flock to a black doctor or lawyer" (Funk 1993, p 1E). In Griffith's attempt to "keep the show honest" to the culture of the South (or at least as he saw it), he perpetrated a dishonesty toward African Americans. The invisibility of African Americans makes Mayberry a racialized place that works to normalize whiteness and creates a racially selective 
image of small town southern life, even though black people clearly inhabit and contribute to these places. This image is perhaps interpreted by some white viewers as nothing out of the ordinary if not comforting, but it can be a distressing depiction for an African American viewing public who feel that they do not belong.

Unlike its television alter ego, Mount Airy does have African American residents. Approximately eight percent of the town's population identifies itself as African American, according to the 2010 U.S. Census figures. In order to begin the process of understanding local views of the celebration of Mayberry in Mount Airy, we held an exploratory focus group discussion with a few African Americans from the area. The participants expressed concern that a celebration of Mayberry is not relatable to their cultural heritage and place attachment. They also argued that the energy and resources spent remaking Mount Airy into Mayberry could be devoted to other job-creation strategies that would, in their view, benefit more locals (Benjamin 2011). The frustration of some local African Americans is perhaps captured best by this online comment during the Rand McNally-USA Today contest: "I am not sure if a town like Mount Airy should be considered for the friendliest city. Maybe it could be the friendliest city as long as you are 'white, and not too different"' (Best of the Road 2011).

Social sustainability emphasizes the importance of local sense of place, but it must also be concerned with understanding the limits of how tourists perceive destinations. Tourism scholars lack an exact idea of the longevity of film-induced tourism, although re-runs, DVD sales, Netflix, and a cult following can extend the popu- larity of media productions. Given the ageing population of television viewers who most watch The Andy Griffith Show, there are important questions about how long this media representation will resonate in Mount Airy as a factor that contributes to its material and social landscapes and sense of place. These questions about generational change are already generating discussion within the town (e.g., Joyce 2011a). Race also plays a role in understanding the changing travel market and the long term viability of film-induced tourism in Mount Airy. Mayberry tourism ignores a growing minority travel market that frequently visits and comes from the South. In fact, North Carolina is the third most visited state by African American travelers (Mandala Research 2011). Research has found that feelings of racial acceptance directly affect the tourism choices of African Americans (Philipp 1999). Mayberry also potentially marginalizes some white tourists who, because of their generational and racial attitudes, wish to connect with a different social image of the region, one that matches their own diverse life experiences and political perceptions of the post-Civil Rights South. Black and white television images of Mayberry may not even connect with conservative young whites in the same intense way as their older counterparts.

\section{A VISIT TO THE \\ MAYBERRY DAYS FESTIVAL}

We visited the Mayberry Days Festival on September 23-26, 2010, staying for the entire 4 days of the festival and attending all planned activities and attractions. Doing so allowed us to document, photographically, as much of the town as possible and interact with as many festival goers 
and locals as possible. The September visit was supplemented with a fact-finding trip earlier in the year (May 2010), research in the archives of the local newspaper, The Mount Airy News, discussions with tourism promoters and local entrepreneurs, and a survey of festival visitors carried out as part of another project (Benjamin 2011). The goal of our project was to understand the landscape changes, tourist practices and performances, and the tensions and contradictions that underlie the remaking of Mount Airy into Mayberry. Guiding our observations is recognition that film tourism promotion transcends simply being a marketing tool and represents a significant and consequential force in reshaping place identity and its material, social, and symbolic components. It is politically consequential in the sense that it gives visibility and legitimacy to certain senses of place and belonging over others.

\section{Landscape Changes}

Naming is an important means of placemaking within tourist destinations. Placenames represent a form of symbolic capital, a way of giving the landscape a comforting cultural value or image that can be marketed to visitors in order to facilitate the exchange of financial capital for a certain place-based experience (Alderman 2008). In transforming Mount Airy into Mayberry, promoters have engaged in a literal rewriting of the town's nomenclature. A playhouse and museum are named after native son Andy Griffith. References to The Andy Griffith Show abound across the landscapes of Mount Airy and the surrounding area, which includes no fewer than 32 businesses that use Mayberry in their name, such as Mayberry Motor Inn,
Mayberry Five \& Dime, Mayberry Pharmacy, and Mayberry Soda Fountain. Other enterprises are named for characters from the show, such as Aunt Bea's [sic] Barbeque and Barney's Café.

A sub-text of nostalgia runs through some of the place-naming and marketing. Visitors patronize stores with names that not only remind them of Mayberry and its characters but also promise to take them back to the good old days. Opie's Candy Store (Figure 1) promises to sell "Old-Tyme Goodies" and Mayberry Primitives markets rustic looking fabrics, decorative arts, and embroidered items. Floyd's Barber Shop, a highly recognizable location in television's Mayberry, has a counterpart in Mount Airy. The establishment was simply known as the City Barber Shop until being changed in the 1980s. According to barber Russell Hiat, he was told to rename the shop when city leaders "started the Mayberry thing." Initially "he was reluctant to do so, but came back to work one day to find that ... [Floyd's] had been added to the window at the City Barber Shop and [he] accepted it as fate" (Schmoll 2006, p 14).

In several cases, like the barber shop, transforming Mount Airy into Mayberry required a renaming of places, suggesting how film-induced tourism development can lead not only to creation of new place associations but also the loss of old ones. The issue of naming has led to controversy in some instances, illustrating how the remaking of Mount Airy is not a settled issue. In the early 1990s, a city commissioner vehemently opposed a suggestion made by visitors that Mount Airy formally rename itself Mayberry. He cited the importance of retaining local identity and controlling "Mayberry-mania" (Joyce 1992, 


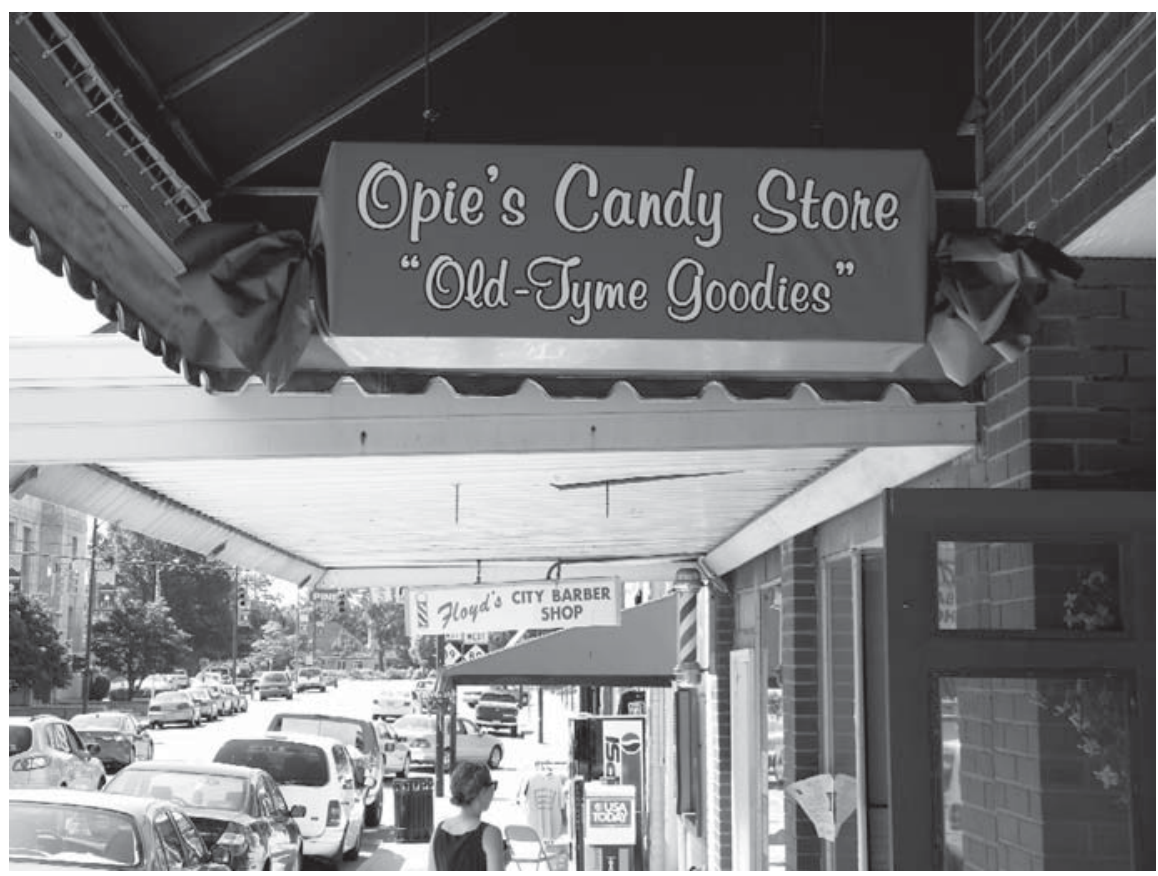

Figure 1. Opie's Candy Store is an illustration of the important role that place-naming plays in the nostalgic remaking of Mount Airy into Mayberry.

p 1). Some of Mount Airy's residents have also proposed renaming the town as well as building a Mayberry theme park (Brown 1997). Place-naming serves as tool for creating and materially projecting a nostalgic Mayberry identity, but it is also an arena for debating it.

In addition to (re)naming places, Mount Airy has engaged in a landscape transformation process that includes replicating places, people, and even sounds from the famous television show. As one walks or drives along Main Street, one can hear a recording of the famous whistling theme song from The Andy Griffith Show's opening credits. Iconic places from the television show have been re-created for tourist con- sumption. Inside the Emporium Gift Store, one can find a re-creation of the Taylor Family's front porch from the television show. A simulated Mayberry Courthouse is located on Main Street, complete with sheriff's desk and jail. Next door to the courthouse is a replica of Wally's Service Station, although some geographic license has been taken since it was not in such close proximity to the courthouse on the show.

Creating a Mayberry sense of place is also facilitated by character look-alikes who roam Main Street and pose for pictures with visitors. James Slate is a re-enactor who plays Mayberry's favorite alcoholic and prisoner, Otis Campbell (Figure 2). Slate is a local, disabled veteran who do- 


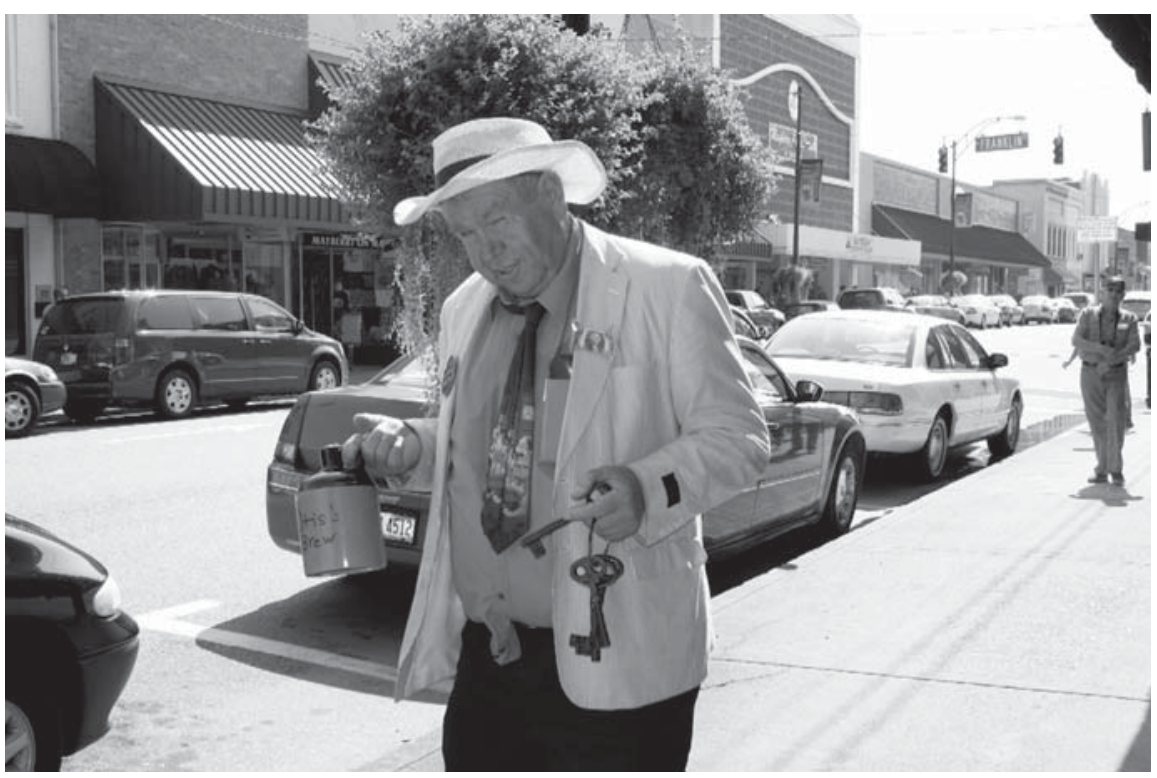

Figure 2. James Slate re-enacts the character of Otis on Mount Airy's Main Street and illustrates the importance the town places on re-creating elements of television's Mayberry.

nates his time to interact with tourists. His son operates one of the Mayberry-themed businesses on Main Street. In April 2011, Slate had more in common with Otis than dressing like him. Mount Airy police arrested him for obstructing a sidewalk, although he said "the incident won't discourage him from continuing to appear as Otis and help promote Mayberry tourism" (Joyce 2011b, p 1). The arrest drew the ire of locals and out of town fans, who claimed that this was a very un-Mayberry thing to do and it hurt the town's friendly image (Best of the Road 2011). The festival's parade is when tourists can see all of Mayberry's characters at once along with visiting celebrities from the show and even people donning masks that look like television sets. The latter display is especially symbolic of the dramatic change of iden- tity that media can bring to a place and its people (Figure 3).

\section{Tourist Practices and}

Performances

Landscape changes represent only half of the story of how Mount Airy is transformed into Mayberry. It is also necessary to consider the bodily performances of place that occur when tourists visit the festival and engage in activities with other visitors and some locals that allow them to re-enact Mayberry and its meaning to them. As Buzinde and her colleagues assert (2010), the production and representation of place through tourism is a coconstructed process shaped by visitors as well promoters. Tourists do not simply consume the remaking of Mount Airy as Mayberry. They actively participate in 


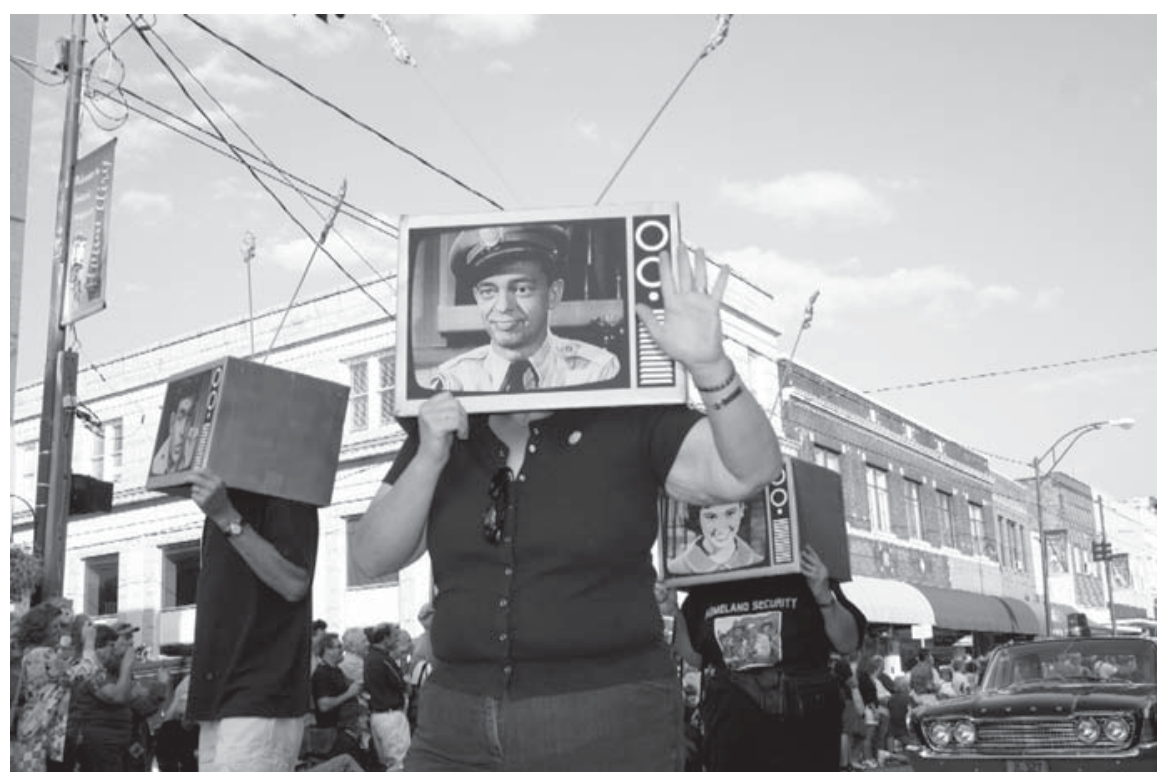

Figure 3. The Mayberry Days Parade is the largest gathering at the festival and a time in which the change of place and personal identity is especially evident.

making the transformation socially important and personally meaningful through the bodily enactment and actualization of place identity.

Tourists carry out social and spatial practices at Mayberry Days that allow them to relive aspects of The Andy Griffith Show and hence contribute to the blurring of real and reel place identity. Buying a pork chop sandwich at Snappy Lunch is one of these practices that contributes to the remaking of place. The diner, established in 1923, was mentioned only twice by name on the show, but it is very popular among tourists. It is seen as direct evidence of the presumed modeling of Mayberry after Mount Airy. Taking a Mayberry Squad Car Tour is also a popular activity for visitors, who ride around Mount Airy in 1960s police vehicles reminiscent of the one Andy Taylor drove as sheriff (Figure
4). Because so many visitors take squad car tours, they ensure that the vehicles are constantly seen along Mount Airy streets, which visually reminds others of Mayberry even if they do not take the tour. A dynamic also happens within the space of the squad car as tourists feel the sensation of "being in Mayberry" and ask the drivers/tour guides about Mount Airy and its relationship to Mayberry and The Andy Griffith Show. This allows visitors to contribute directly to the re-enactment and remaking of place.

Another important tourist practice is getting a haircut at Floyd's Barber Shop (Figure 5). Russell Hiatt, who owns and operates the barber shop, is mistakenly identified by tourists as the character model for Floyd, the barber on The Andy Griffith Show (Schmoll 2006). Hiatt does not claim to be Floyd and admits that he only cut Andy Griffith's hair a few times 


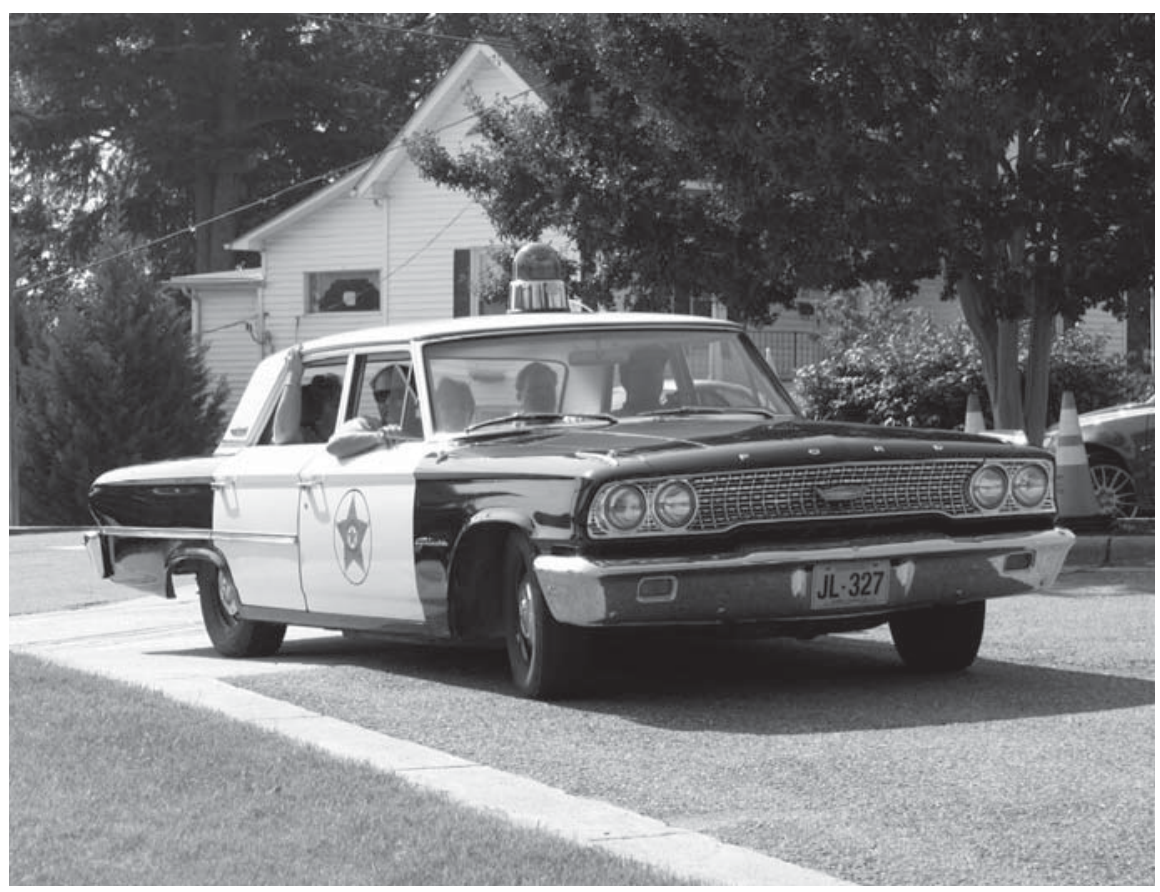

Figure 4. Taking a police squad car tour is a popular way for tourists to construct for themselves and onlookers the feeling of "being in Mayberry."

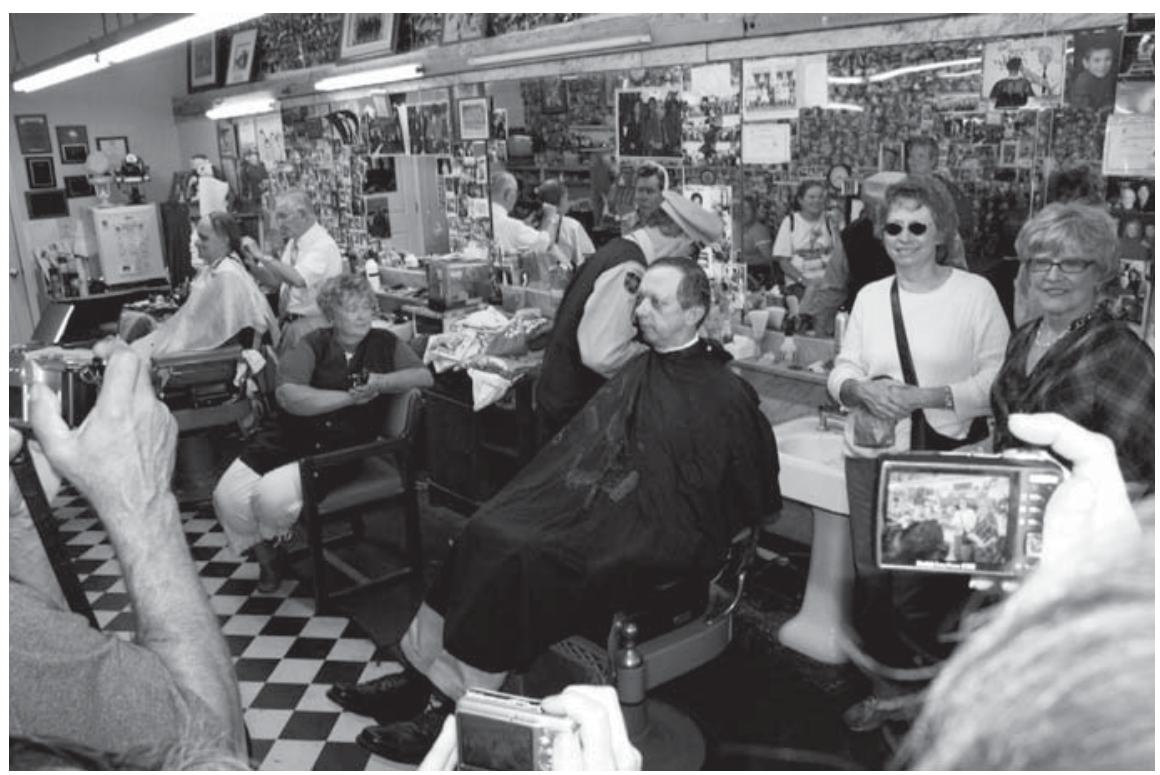

Figure 5. Getting a haircut at Floyd's Barber Shop is a personally meaningful practice for some tourists as they relive a common scene from the television show and, in doing so, reproduce Mayberry. 
when the actor was home from college. According to Brown (1997, p 190), many tourists do not challenge these inconsistencies or the confusing mixture of television memories with actual life stories. "Mayberry is real, they argue, because Mount Airy is real; Sherriff Andy Taylor is real because Andy is real." The fact that tourists "appear to appreciate the 'authentic' in a world ... that trades directly on blurring fantasy and reality" is not unique to Mount Airy but symptomatic of film tourism more generally, illustrating the important role that embodied experiences of place play in judgments of authenticity by tourists (Buchmann et al. 2010, p 243).

As one witnesses at Floyd's, the bodily performance of "being in Mayberry" is often accompanied by visitors taking pictures. Indeed, there is little in Mount Airy related to The Andy Griffith Show not heavily photographed by tourists. Taking pictures obviously provides souvenirs, but it also represents a place-making practice in its own right. Because these pictures are shared with others at the festival and later after going home, they help to further legitimize the Mayberry identity and provide visual proof to themselves and others of how much Mount Airy was indeed like Mayberry.

As Kim (2010) has pointed out, there is a general lack of research on tourist performances such as re-enactment and photography at film-related destinations, even though he found such practices to be an important part of the tourist experience. Tourists, according to him, do not merely want to gaze upon a site/sight, but personally engage and emotionally experience what they see at film tourism locations-"to develop a bond, person-place coupling, and a sense of belonging, to the extent that these places become "their place" (Kim 2010, p 62). This emotional connection with Mayberry obviously enhances the tourism experience, but it potentially sets up a situation in which there can be competing claims to place and belonging.

The Mayberry Days Festival attracts a wide range of visitors-from the die-hard fan to the more casual participant. Some of the visitors to Mount Airy are tribute artists who become part of the festival's cast of character look-a-likes who entertain other tourists. Re-enacted characters are popular and tourists frequently ask for autographs. Artists sign the name of their characters while also speaking and acting like them. Collecting these autographs, which requires an active and willing suspension of disbelief, is another bodily practice that serves to verify "being in Mayberry."

Clothes and the act of "dressing the part" are important tourist practices that transform Mount Airy into Mayberry. This is evident not only among the professional re-enactors but also among the many fans who buy Andy-themed hats and T-shirts that proclaim: "What Happens in Mayberry Stays in. . . . Your Heart." Tourist performances can be structured by local promoters, such as businesses providing hats and T-shirts for purchase. However, the performances can also be characterized by a certain measure of improvisation as tourists produce (and reproduce) the meaning and materiality of destinations (Edensor 2001). Some visitors show up to the festival with their own Mayberryrelated clothes and outfits, such as one young man who came to the festival dressed as Barney and with his own bullet! (Figure 6). 


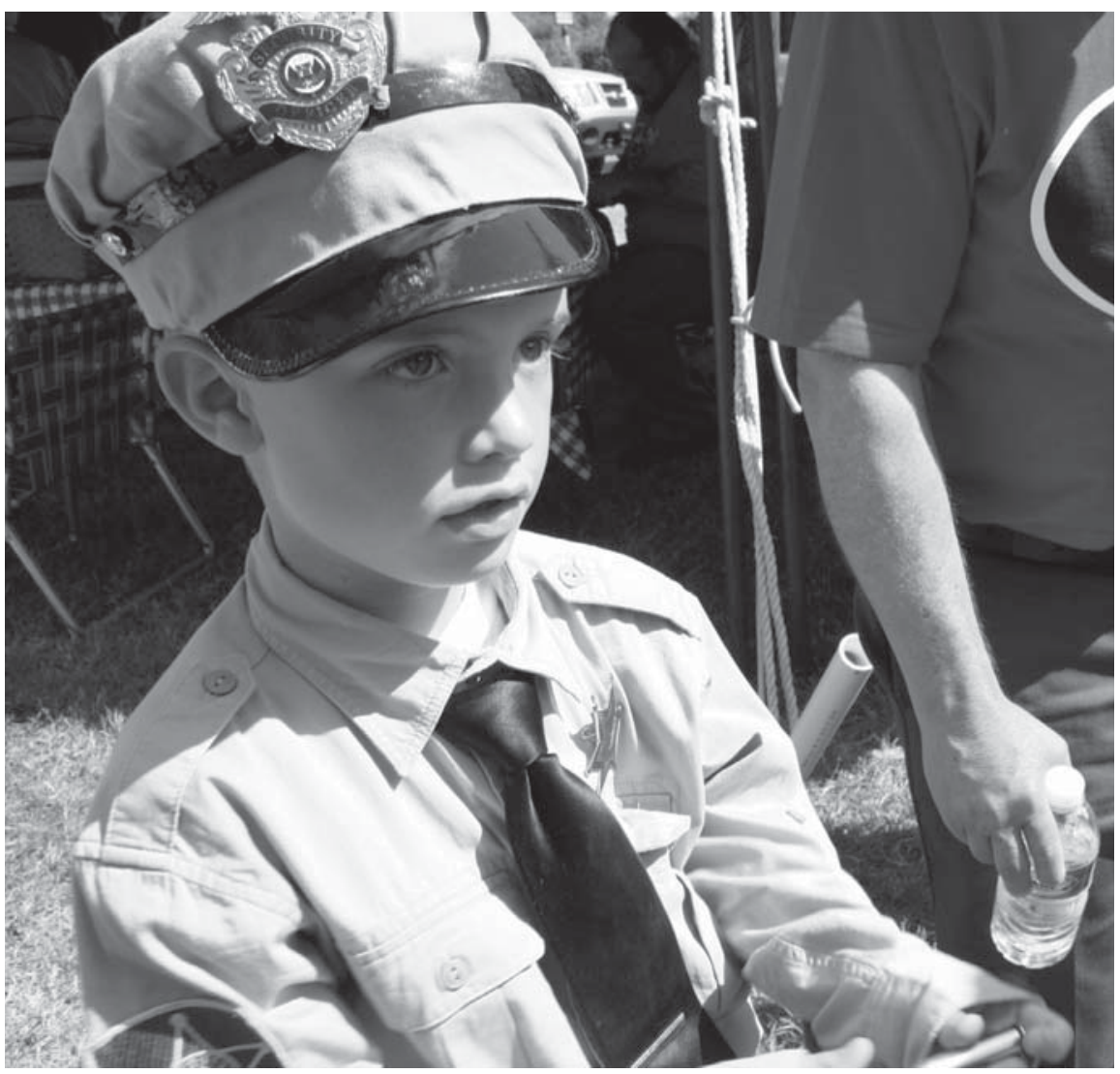

Figure 6. Dressing the part of a character, in this case Barney Fife, is an important way by which visitors connect bodily with the idea of transforming Mount Airy into Mayberry.

Tensions and Contradictions

Despite what appears to be an effortless transformation of Mount Airy into Mayberry for tourists and local fans, we found evidence that this place-making is open to tension, either realized or potential. It is true that Mayberry can be interpreted as a harmonious, utopian community accepting of the "Other" or the marginalized (Flanagan 2009). However, Mayberry is also open to being interpreted as a dystopian community that practices social exclusion as well as social acceptance (Alder- man et al. 2011). The promotion of Mount Airy as Mayberry, as Morgan (2004, p 175) would argue, is not simply a matter of marketing, but a cultural process that gives some social groups more power to be seen and heard than others.

With no significant African American presence on The Andy Griffith Show, it is perhaps not surprising that we saw few African American locals and tourists at the 2010 Mayberry Days festivities. The exclusion of African Americans from Mayberry was problematic in the 1960s during the 
push for racial equality, but it is an especially disturbing image in the post-Civil Rights era as it appears to be perpetuated in Mount Airy. We saw only six African American visitors out of thousands of white people who attended the Mayberry Days Festival in 2010. Moreover, a survey of festival goers that we carried out as part of another project yielded only one African American and one Hispanic out of 122 respondents (Benjamin 2011).

The reproduction of a virtually allwhite Mayberry belies the historical and contemporary role of African Americans in Mount Airy. The Civil Rights Movement was never an issue in television's Mayberry, but this was not the case in Mount Airy. In 1963, just a few years after the start of The Andy Griffith Show, Mount Airy police arrested 10 black youth for demanding service at two drug stores and refusing to leave. In 1968, the last year of production for the show, the Mount Airy YMCA finally opened its doors to African Americans, doing so in winter so as to avoid community reaction to the swimming of both races in the outdoor pool together (Curtis 2002). Because these struggles never happened in the all white television community of Mayberry, it is less likely they will be given sufficient public attention in a Mount Airy selling and remaking itself as Mayberry. With the remembering of Mayberry invariably comes a forgetting of other ideologically incompatible pasts. Curtis (2002) is critical of how nostalgic images of Mayberry take on the power of history for Andy Griffith fans and occlude the history of African Americans in Mount Airy. She offers this advice to fans and town promoters: "Nostalgia is fine. Enjoy Mayberry, just don't mistake a southern fairy tale for the truth."

The occlusion of African American his- tory within Mount Airy has not gone unchallenged, however. In 2009, during the busy Saturday morning activities of the Mayberry Days Festival, the Surry African American Historical/Genealogical Society met at a local church to hold an essay contest for area black children and youth to present their writings about the past (Peters 2009). In response to request from members of the African American community, the Andy Griffith Playhouse and the Surry Arts Council began hosting an annual musical program in observance of Black History Month (Phillips 2007). Every February for the past several years, the Surry County African American Heritage Council and NAACP have organized a Black Heritage Parade in downtown Mount Airy. Segments of the broader white community have also been involved in reversing the neglect of African American historical contributions, such as the preservation and dedication of a slave cemetery in 2010 by the Surry County Historical Society and the hosting of several exhibits and programs at the Mount Airy Museum of Regional History, including a 2011 traveling show on local African American house builders (Evans 2010; Tilley 2011). Yet, we are unsure about how many Mayberry Days tourists actually see and internalize these noteworthy efforts to promote local African American heritage, particularly since the festival occurs in September and much of the town's celebration of black heritage takes place during the months of January and February.

Socially responsible approaches to tourism call on us to recognize not only the place histories of African Americans but also the historical and racial context within which the idea of Mayberry was first created. As Graham (2003, p 158) noted, The Andy Griffith Show was a "weekly testament to 
the ideal of minimal social change." According to her (2003, p 160), "Mayberry was CBS's prime-time challenge to its own evening newscast. Coming into living rooms in the 'family' hours following Walter Cronkite's stories from Birmingham and Selma, it suggested a different kind of realism-one of selective memory, silences, and omissions." From the beginning, Mayberry was imagined as a place where white America could escape the realities of race relations. Today, invocations of Mayberry in Mount Airy run the danger of perpetuating a similar escape. Such an escape, while allowed to happen on television in the 1960s, should not be the basis for developing and promoting a $21^{\text {st }}$ Century community that, indeed, has living and breathing African Americans.

The transformation of Mayberry into Mount Airy is also complicated by contradictions that invariably arise when a town with imperfections and problems closely identifies itself with a fictional, utopian community. As we found in Mount Airy, life does not always imitate art. The town shows signs of social tension uncharacteristic of the idyllic Mayberry. During the festival, the owner of a local pool hall called Hustler's posted signs accusing the city of being anti-small business and racist, citing the lack of African American police officers (Joyce 2010c) (Figure 7). He created a place identity narrative that openly challenged the idealized image of Mayberry, where racial tension and pool halls have no place. Foreclosures and unemployment also rarely made a television appearance in Mayberry. In contrast, Mount Airy has seen a major decline of textile and apparel manufacturing. It is a reality that the idyllic Mayberry place identity is unable to make sense of and probably would prefer not to deal with. As Packer (2011, p 70) recently observed, "the picture of small town nostalgia [in Mount Airy] crumbles in the surrounding streets, where dozens of factories-some the size of a small house, others several blocks longare boarded up. Surry County, which has a population of seventy-two thousand, has lost ten thousand jobs in the decade since 9/11."

Much of Mayberry tourism promotes Andy Griffith's real life and his reel life as Sheriff Andy Taylor. Differentiating the two Andys can be as difficult as separating Mount Airy from Mayberry, as evidenced when Sheriff Taylor's conservative image conflicts with Griffith's actual political life. For example, some Mayberry enthusiasts boycotted Mount Airy after Griffith, a long-time Democrat, appeared in commercials supporting Barack Obama's presidential bid and healthcare plan (Tilley 2010). Other locals and visitors express frustration that Andy rarely attends the Mayberry Days Festival; indeed, he has only returned to his hometown a few times in the past 50 years. He lives in the state, but over 300 miles away near the Outer Banks. In one of Griffith's few trips to the town, he attended the dedication of a statue in front of the Andy Griffith Playhouse. The statue displays the iconic image of Andy Taylor and his son, Opie, walking hand in hand to their fishing hole (Figure 8). In 2010, vandals defaced the statue, dousing Andy's hair with green paint and his mouth and badge with red paint. Mount Airy police never caught the culprit (Joyce 2010a). This is not the first time the statue has generated controversy. In 2003, angry Mayberry fans and Mount Airy promoters petitioned TV Land for the statue-which is actually the second of its kind (Youngquist 2003). The first was placed in Raleigh, 


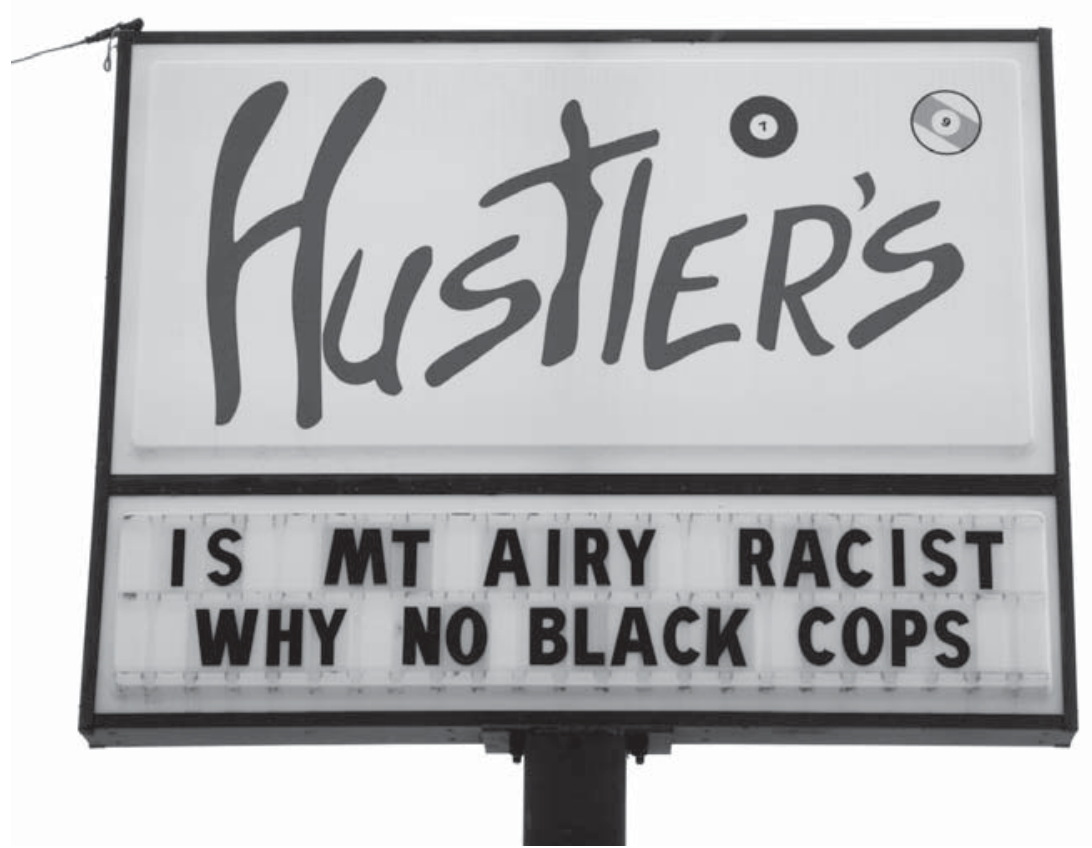

Figure 7. The owner of Hustler's pool hall used his business sign to call public attention to race relations within the town of Mount Airy, directly challenging the idyllic Mayberry identity. While these claims of racism were challenged by city leaders, this was not the first time this issue had been raised publicly.

North Carolina, snubbing Mount Airy and its claims to being the inspiration for Mayberry. The statue, unlike Andy Griffith, finally came home.

As we indicated earlier, many Mayberry tourists visit Mount Airy out of a sense of nostalgia, a yearning to reconnect with the idea of "a simpler time" and "a sweeter place" as described on the plaque in front of the Andy and Opie statue. No doubt, this partly explains the fact that older tourists clearly outnumber other age cohorts at the festival. It is this group that perhaps looks back to the past, or an idealized past, more than younger people. A survey of festival goers reveals that their average age is 51-65 years and that an overwhelming 94 percent of respondents watched The Andy Griffith Show as children, all of which prompts us to consider the generational sustainability of Mayberry's incarnation in Mount Airy (Benjamin 2011). This recent survey notwithstanding, tourism leaders in Mount Airy have not devoted significant attention to developing a tourist profile that would assist them in tracking new and returning visitors. There is already evidence of debates and discussions in Mount Airy about the shelf-life of Mayberry tourism. As an editorial letter writer expressed in The Mount Airy News: "There is . . . concern that, as a younger generation monopolizes tourism dollars ... Andy [Griffith] will be 


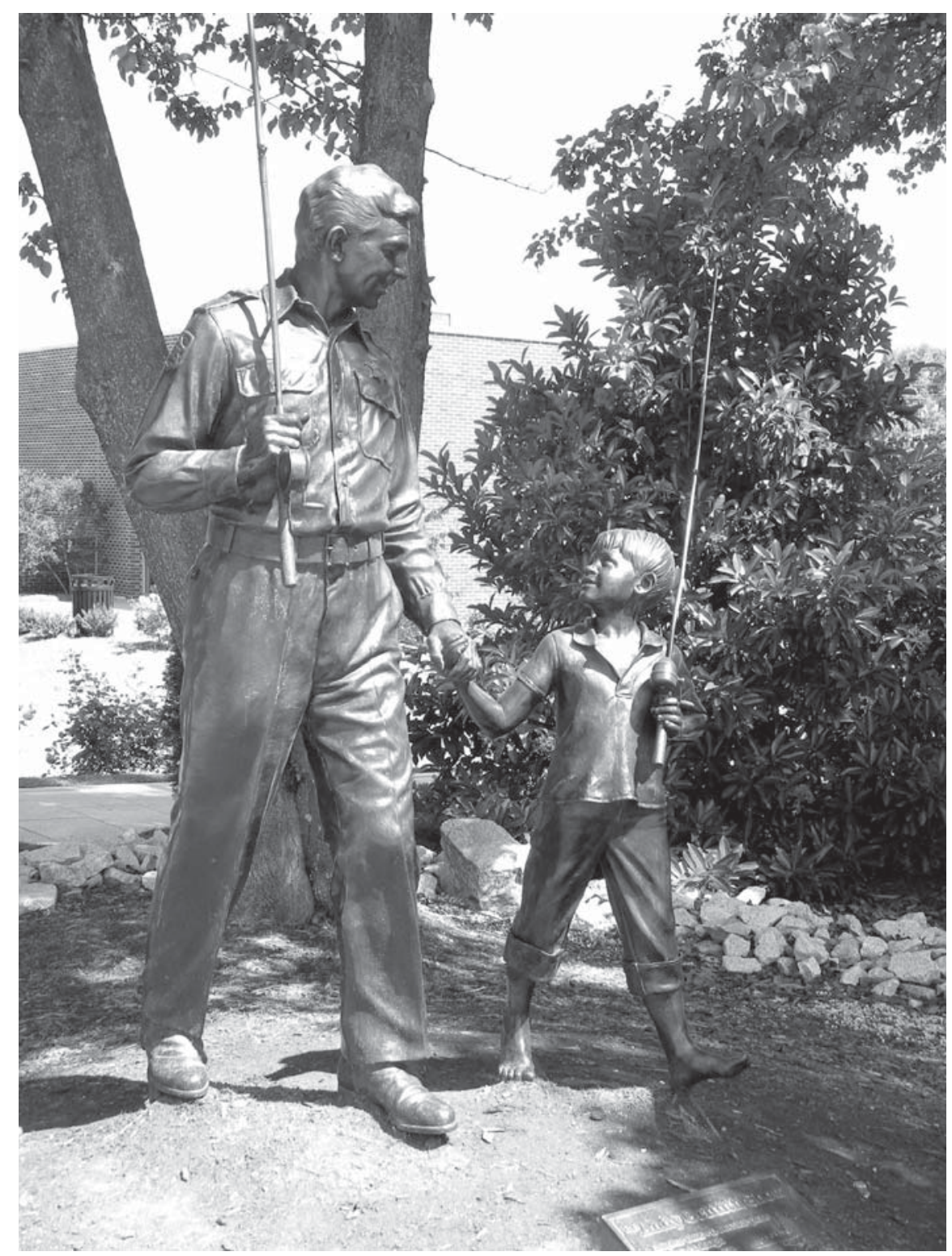

Figure 8. The statue of Andy and Opie is a popular landmark in Mount Airy and, in 2010, the target of vandalism, possibly reflecting the social tensions that underlie Mayberry tourism. 
less of an attraction. And while we can't discount the continuing allure of Mayberry ... the time may well come when our vineyards, rich heritage, recreation potential and scenic vistas are the drawing factor for more tourists than the fact the town was Andy's birthplace" (Anonymous 2007, p 4)

Nostalgia creates emotional spaces within which people make decisions and take actions. A large share of surveyed visitors (97 percent) indicate that Mount Airy would be a nice place to live, and it is not uncommon to hear about past festival visitors who later decide to relocate to the North Carolina town (Benjamin 2011). At the same time that nostalgia can advance people's love for certain places, it can create overly idealized place expectations that any city or town would find difficult to meet. In 2007, Betty Lou Lynn, a long-time festival visitor, made the decision to move from California to Mount Airy. Lynn appeared on The Andy Griffith Show, playing Barney Fife's long-time girlfriend, Thelma Lou. In 2010, Betty Lou was robbed of her wallet in a Mount Airy shopping center. Ironically, Lynn moved to Mount Airy wishing to avoid the big-city crime of Los Angeles (Joyce 2010b). The robbing of Thelma Lou (many locals in Mount Airy call her that instead of her given name) received regional and national media attention, exposing the city and its Mayberry image to possible public ridicule.

Some tourism promoters and Andy Griffith fans can be defensive about Mount Airy's connection to Mayberry. In September of 2010, a young man in his twenties from Mount Airy went on the Mayberry Days Facebook page to complain about how the festival was not bringing in enough revenue to the town of Mount Airy in order to sustain it for the whole year, citing the need for more jobs for locals. The young man was heavily rebuked for his comments, with one person responding: "Why are you on this page? Can someone delete him? ... nobody is gonna talk bad about Andy or Mount Airy . . . love to see you get kicked out of town completely." The person complaining was soon removed from the conversation by the manager of the Facebook page, who wrote: "Its Mayberry Days, no negative energy." While this is just a single online exchange, it is instructive of how the remaking of Mount Airy can be open to challenges about its fairness and sustainability. The maintenance of a Mayberry place identity requires, ironically, a rather unfriendly de-legitimizing of counter constructions of place. By contrast, socially sustainable approaches to tourism value public input rather than shut it down.

\section{CONCLUDING REMARKS}

In an episode of The Andy Griffith Show entitled "Mayberry Goes Hollywood," the traditional, small-town look of Mayberry catches the attention of a movie producer interested in using the town as a film location. Easily intimidated and swayed by outside public scrutiny, Mayberrians respond to this interest from Hollywood by changing the town's appearance, putting on new and different clothes, and adopting fake personalities. In the episode's climax, Andy and the film producer "are barely able to stop the citizens, who now look something like a well-dressed lynch mob, from cutting down the town's most ancient oak because they think it is spoiling the appearance of the main street" (O'Leary and Worland 2005, p 78-79). This storyline drips with irony when we consider the place-remaking that Mount Airy has undergone to 
please the expectations of television audiences seeking to reconnect with the mythical hamlet of Mayberry. As the near cutting down of the oak tree in the episode suggests, there can be potentially negative consequences to giving into the pressure of being something, socially, that you are not.

Admittedly, not all movie or televisionrelated destinations transform themselves to the extent that Mount Airy has done. Yet, the North Carolina town is emblematic of a larger remaking of place and place identity that occurs in many communities as they conflate the "real" and the "reel" through film-induced tourism. While this conflation can serve as the basis for economic development, it is anything but inconsequential for the people and places of the destination. We identified a variety of social practices involved in transforming Mount Airy into Mayberry: the renaming of places, the building of place replicas, the use of character re-enactment, and the bodily performance of place by tourists through autograph collecting, touring the city, photography, dress, and the simple tasks of eating and getting a haircut. While town promoters create and capitalize upon the ambiguity between Mount Airy and Mayberry, blurring these lines of distinction does not resonate with everyone, including Andy Griffith himself. This reworked place identity comes with certain tensions and contradictions that will ultimately limit its social sustainability based on the ageing demographic attracted to The Andy Griffith Show, the racially diversifying travel market in general, and the sheer insensitivity of promoting tourism in the contemporary South using media images that so clearly ignore the region's civil rights history. Achieving social responsibility in tourism ultimately depends upon addressing the different ways people perceive, experience, and identify with Mount Airy, both inside and outside the context of Mayberry.

Mayberry tourism normalizes a nostalgic place identity that disenfranchises African Americans and others even as it is represented as an innocent return to a simpler and kinder time and place. This exclusion can have profound impacts on the sense of belonging felt by both locals and potential visitors. Future work should delve more deeply into understanding how residents, especially African Americans, feel about living in "the real life Mayberry" and how much (or how little) they benefit economically and socially from film-induced tourism in Mount Airy. While such studies can be carried out through standard methodologies such as questionnaires, interviews, and focus groups, we also believe that auto-photography is a viable method given the strong visual qualities of Mount Airy's transformation into Mayberry. Auto-photography would involve providing cameras to a group of African American residents, asking them to document what they like and dislike about Mount Airy, and then interviewing participants about their photographs in order to unlock deeper perceptions and senses of place.

In suggesting a more sustainable and responsible path for Mount Airy tourism, we see at least two options. First, Mount Airy promoters can continue the process of identifying and developing other tourism opportunities, especially those that highlight and take advantage of the area's existing cultural and natural assets rather than relying upon a place identity manufactured on a movie lot and in a different social and historical context. Given that 
some of the Mayberry Days visitors we surveyed said they had come to Mount Airy because they were looking for a simple, friendly atmosphere and not just the Andy Griffith connection (Benjamin 2011), it might be possible to promote Mount Airy's rural, small-town feel without interpreting it through the racialized lens of a 1960s American television. This would not necessarily mean abandoning the very real connection that Andy Griffith, the actor, has with Mount Airy, but rather that tourism would focus on the community in which he grew up and not the fictional town he created on television. Some of this narrative already exists, but it would require a much greater presentation of local stories and perspectives, including those of the African American community.

A second approach for Mount Airy might involve a significant revision of Mayberry tourism rather than simply moving away from it. Given the obvious difficulty that will come in de-coupling Mayberry from Mount Airy's image and landscape, promoters might consider producing a "remake" or "adaptation" of Mayberry, to use terms from the film industry. Classic television shows and movie productions are remade all the time, and producers frequently recognize that the time and place context of an original performance and plot may no longer resonate culturally or politically. Rather than simply "replicating" The Andy Griffith Show, Mount Airy might actively explore what an up-to-date and more racially diverse Mayberry adaptation would look and feel like on the streets of Mount Airy. Doing so would require consciously re-imagining Mayberry as a social ideal rather than treat it as a museum piece. Of course, some Andy Griffith Show purists will not appreciate this revision, but it is also possible that other fans might be willing to think of Mayberry in alternative, more progressive ways. Indeed, The Andy Griffith Show, like many pop culture productions, has inspired its own body of fan fiction in which enthusiasts create and develop storylines and social situations that take place in Mayberry but move beyond the original television episodes.

Whatever path is taken in moving forward, locals, particularly African Americans, should be actively involved in these decisions. Broad-based, local involvement in tourism planning is another hallmark of sustainable tourism. Indeed, one of the anonymous reviewers of this paper astutely called for an "integrated human and economic development" approach that "would ideally require open and transparent discussion about what it is like (and should be like) to live in Mount Airy." Beyond the local impact of such discussions, Mount Airy could represent an important "site of intervention" in reforming traditional ideas of southern hospitality, challenging conventional media images of small town life and heritage, and incorporating social justice and African American belonging into place-making through tourism.

\section{ACKNOWLEDGEMENTS}

The authors wish to thank the two anonymous reviewers of this paper and the journal's editors for their helpful comments on the manuscript. Appreciation is also extended to East Carolina University's Center for Sustainable Tourism, which assisted in funding the study of Mayberry-related tourism in Mount Airy, North Carolina. Finally, we wish to thank all of the locals, tourists, and tourism promoters/entrepreneurs in Mount Airy who spoke with us, agreed to be photographed, and 
shared their views and opinions at the 2010 Mayberry Days Festival.

\section{REFERENCES}

Adams, P.C. 2009. Geographies of media and communication: A critical introduction. Malden, MA: Wiley-Blackwell.

Aitken, S.C., and Zonn, L. eds. 1994. Place, power, situation, and spectacle: A geography of film. Lanham, MD: Rowman \& Littlefield.

Alderman, D.H. 2008. Place, naming, and the interpretation of cultural landscapes. In The Ashgate research companion to heritage and identity, eds. B. Graham and P. Howard, 195-213. Burlington, VT: Ashgate Press.

Alderman, D.H., and Modlin, E.A., Jr. 2008. (In)visibility of the enslaved within online plantation tourism marketing: A textual analysis of North Carolina websites. Journal of Travel and Tourism Marketing 25: 265-281.

—. Forthcoming. Southern hospitality and the politics of African American belonging: An analysis of photographs in North Carolina tourism brochures. Journal of Cultural Geography.

Alderman, D.H., Moreau, T., and Benjamin, S.K. 2011. The Andy Griffith Show: Mayberry as working class utopia. In Blue collar popular culture: television, ed. M.K. Booker, 51-69. Westport, CT: Praeger Publishers.

Anonymous. 2007. "Time to move on." The Mount Airy News, 20 January 2007, p 4.

Antonsich, M. 2010. Search for belonging: An analytical framework. Geography Compass 4:644-659.

Archive of American Television. 1998. Interview with Andy Griffith (by Michael Rosen). Accessed 10 June 2011 at http:// www.emmytvlegends.org/interviews/ people/andy-griffith.

Bandyopadhyay, R., and Nascimento, K. 2010. "Where fantasy becomes reality": How tourism forces made Brazil a sexual playground. Journal of Sustainable Tourism 18:933-949.

Becker, K. 2002. "Back to Mayberry." The Toronto Star, 2 June 2002, p T8.

Beeton, S. 2001. Smiling for the camera: The influence of film audiences on a budget tourism destination. Tourism, Culture \& Communication 3:15-25.

—. 2005. Film-induced tourism. Buffalo, NY: Channel View Publications.

—. 2006a. Community planning through tourism. Collingwood, Australia: Landlinks Press.

—. 2006b. Understanding film-induced tourism. Tourism Analysis 11:181-188.

Benjamin, S.K. 2011. "Lost in Mount Airy/Mayberry: The importance of tourist profiles in sustainable tourism planning." Unpublished M.S. Thesis. East Carolina University. ProQuest (AAT 1493561).

Best of the Road. 2011. "Mount Airy, NC." Reviews and Photos-Best of the Road by Rand McNally and USA Today. Accessed 9 June 2011 at http://www.bestoftheroad .com/town.do?destinationId $=6605$.

Bly, L. 2010. "The spirit of Mayberry lives on in Mount Airy; 'The Andy Griffith Show' keeps town on the map-and in people's hearts." USA Today, 10 September 2010, p 4D.

Bramwell, B., and Bernard, L. 2008. Priorities in sustainable tourism research. Journal of Sustainable Tourism 16:1-4.

Brown, R.L. 1997. Ghost dancing on the cracker circuit: The culture of festivals in the American South. Jackson, MS: University of Mississippi Press.

Buchmann, A., Moore, K., and Fisher, D. 2010. Experiencing film tourism: Authenticity \& fellowship. Annals of Tourism Research 37:229-248.

Burgess, J., and Gold, J. eds. 1985. Geography, the media \& popular culture. New York, NY: St. Martin's Press. 
Butler, R. 2011. It's only make believe: The implications of fictional and authentic locations in films. Worldwide Hospitality and Tourism Themes 3:91-101.

Buzinde, C., Manuel-Navarrete, D., Kerstetter, D., and Redclift, M. 2010. Representations and adaptation to climate change. Annals of Tourism Research 37:581-603.

Byrd, E.T. 2008. Autumn Leaves Festival economic impact study. Prepared for the Greater Mount Airy Chamber of Commerce \& Mount Airy Visitors Center.

Carl, D., Kindon, S., and Smith, K. 2007. Tourist's experiences of film locations: New Zealand as "Middle Earth." Tourism Geographies 9:49-63.

Cole, S., and Morgan, N. eds. 2010. Tourism and inequality: Problems and prospects. Cambridge, MA: CABI.

Cresswell, T., and Dixon, D. 2002. Engaging film: Geographies of mobility and identity. Lanham, MD: Rowman \& Littlefield.

Curtis, M. 2002. "Where were Mayberry's black people?" Charlotte Observer, 3 November 2002, p 1G.

Curtis, W. 2010. Whistle if you love Andy Griffith. AARP: The Magazine July/August: 47-65. Accessed 29 January 2012 at http://www.aarp.org/entertainment/ television/info-05-2010/whistle-if-youlove-andy-griffith.html.

Davis, J.S. 2005. Representing place: "Deserted Isles" and the reproduction of Bikini Atoll. Annals of the Association of American Geographers 95:607-625.

DeLyser, D. 2003. Ramona Memories: Fiction, tourist practices, and placing the past in Southern California. Annals of the Association of American Geographers 93:886-908.

Dickson, S. 2004. In search of Mayberry: A guide to North Carolina's favorite small towns. Boone, NC: Parkway Publishers, Inc.
Edensor, T. 2001. Performing tourism, staging tourism: (Re)producing tourist space and practice. Tourist Studies 1: 59-81.

—. 2009. Tourism. In International Encyclopedia of Human Geography (Volume 11), eds. R. Kitchin and N. Thrift, 301-312. Boston, MA: Elsevier.

Evans, M. 2010. "Slave cemetery dedicated." The Mount Airy News, 27 August 2010, p 1 A.

Fann, J. 2001. The way back to Mayberry: Lessons from a simpler time. Nashville, TN: B\&H Publishing Group.

Flanagan, J. 2009. Deconstructing Mayberry: Utopia and racial diversity in the Andy Griffith Show. Continuum: Journal of Media \& Cultural Studies 23:307-319.

Funk, T. 1993. "This is Andy, plain-spoken.” Charlotte Observer, 7 February 1993, p 1E.

Garofoli, J. 2010. "Forks reborn as 'Twilight' tween mecca." San Francisco Chronicle, 16 July 2010, p E1.

Hahm, J., and Wang, Y. 2011. Film-Induced tourism as a vehicle for destination marketing: Is it worth the efforts. Journal of Travel \& Tourism Marketing 28:165-179.

Hanna, S.P. 1996. Is it Rosyln or is it Cicely? Representation and the ambiguity of place. Urban Geography 17:633-649.

Hanna, S.P., Del Casino, V.J., Jr., Selden, C., and Hite, B. 2004. Representation as work in "America's Most Historic City." Social \& Cultural Geography 5:459-481.

Hudson, S., and Ritchie, J.R.B. 2006. Promoting destinations via film tourism: An empirical identification of supporting marketing initiatives. Journal of Travel Research 44:387-396.

Hudson, S., Wang, Y., and Gil, S.M. 2011. The influence of a film on destination image and the desire to travel: A cross-cultural comparison. International Journal of Tourism Research 13:177-190. 
Imrie, R. 2006. "B\&B recreates Andy Griffith's Mayberry home." USA Today. Accessed 20 December 2011 at http://www.usatoday .com/travel/hotels/2006-07-24-mayberrybnb_x.htm.

Janiskee, R.L., and Drews, P.L. 1998. Rural festivals and community reimaging. In Tourism and recreation in rural areas, eds. R. Butler, C.M. Hall, and J. Jenkins, 157175. New York, NY: John Wiley \& Sons.

Jewell, B., and McKinnon, S. 2008. Movie tourism-a new form of cultural landscape. Journal of Travel \& Tourism Marketing 24:153-162.

Johnson, C.Y., Halfacre, A.C., and Hurley, P.T. 2009. Resistant place identities in rural Charleston County, South Carolina: Cultural, environmental, and racial politics in the Sewee to Santee area. Research in Human Ecology 16:1-16.

Joyce, T. 1992. "Lowry to quash Mayberry mania." The Mt. Airy News, 2 July 1992, p 1.

—. 2010a. "Vandals strike statue." The Mount Airy News, 23 February 2010, p 1.

—. 2010b. "'Thelma Lou' is victim of robbery." The Mount Airy News, 29 April 2010, p 1.

—. 2010c. "Signs at local business attack city government." The Mount Airy News, 20 August 2010, p 1.

—. 2011a. "How long is the 'Mayberry Thing' going to last." The Mount Airy News, 14 May 2011, p 4.

_. 2011b. "'Otis' at odds with police.” The Mount Airy News, 20 May 2011, p 1.

Kellner, D. 1988. Postmodernism as social theory: Some challenges and problems. Theory, Culture \& Society 5:239-269.

Kerstetter, D., and Bricker, K. 2009. Exploring Fijian's sense of place after exposure to tourism development. Journal of Sustainable Tourism 17:691-708.

Kim, S. 2010. Extraordinary experience: Re- enacting and photographing at screen tourism locations. Tourism and Hospitality Planning \& Development 7:59-75.

Kutzer, J.M. 2001. Memories of Mayberry. St. Augustine, FL: Dynamic Living Press.

Lukinbeal, C. 2004. The map that precedes the territory: An introduction to essays in cinematic geography. Geojournal 59:247-251.

Mandala Research. 2011. The African American traveler. Alexandria, Virginia: Mandala Research, LLC.

Mitchell, M. 2011. "A Mayberry image update?" Winston-Salem Journal, 12 February 2011, p A1.

Morgan, N., 2004. Problematizing place promotion. In A companion to tourism, eds. A. Lew, C.M. Hall, and A.M. Williams, 173183. Malden, MA: Blackwell Publishing.

Nowell, P. 2002. "Andy of Mayberry back in its model, Mount Airy." The Herald-Sun, 17 October 2002, p A1.

O'Connor, N., Flanagan, S., and Gilbert, D. 2010. The use of film in re-imaging a tourism destination: A case study of Yorkshire, UK. Journal of Vacation Marketing 16:61-74.

O'Leary, J., and Worland, R. 2005. Against the organization man: The Andy Griffith Show and the small-town family ideal. In The sitcom reader: America viewed and skewed, eds. M. Dalton and L. Linder, 73-84. Albany, NY: University of New York Press. Packer, G. 2011. Coming apart. New Yorker 87(27): 62-71.

Peters, J. 2009. "Learning about one another." The Mount Airy News, 27 September 2009, $\mathrm{p} 4 \mathrm{~A}$.

Philipp, S., 1999. Are we welcome? African American racial acceptance in leisure activities and the importance given to children's leisure. Journal of Leisure Research 31:385-403.

Phillips, J.D. 2007. “Arts council tailors events 
to observe Black History Month." The Mount Airy News, 8 February 2007, p 1.

Riley, R., Baker, D., and Van Doren, C.S. 1998. Movie-induced tourism. Annals of Tourism Research 25:919-935.

Roesch, S. 2009. The experiences of film location tourists. Bristol, UK: Cannel View Publications.

Rosati, C. 2007. Media geographies: Uncovering the spatial politics of images. Geography Compass 1:995-1014.

Sack, K. 1997. "Mount Airy journal; Reality plays a bit part on Mayberry Days." The New York Times, 29 September 1997, p A1.

Sanes, K. 2010. "Andy Griffith and comedy's healers." Accessed 30 January 2012 at http://www.transparencynow.com/andygriffith.htm.

Schmoll, A. 2006. "Hiatt celebrating 60 years at Floyd's Barber Shop." The Mount Airy News, 3 July 2006, p 1.

Surry County Arts Council. 2010. "Sponsor opportunities.” Accessed 26 December 2011 at http://www.surryarts.org/mayberryd ays/md10sponsorshipreport.pdf.

Tilley, M. 2010. "Two cancel travel plans due to ad." The Mount Airy News, 8 August 2010, p 1A.

—. 2011. "Museum members preview new African-American builders exhibit." The Mount Airy News, 17 September 2011, p 1.

Vaughn, D.R. 2004. Why The Andy Griffith Show is important to popular cultural studies. The Journal of Popular Culture 38:397-423.

Young, A.F., and Young, R. 2008. Measuring the effects of film and television on tourism to screen locations: A theoretical and empirical perspective. Journal of Travel \& Tourism Marketing 24:195-212.

Youngquist, S.W. 2003. "Mount Airy petitions for statue of Andy, Opie." Winston-Salem Journal, 5 April 2003, p 1B.
Zonn, L., ed. 1990. Place images in media: Portrayal, experience, and meaning. Savage, MD: Rowman \& Littlefield.

DEREK H. AlDERMAN is Professor and Head of the Department of Geography at the University of Tennessee, Knoxville, TN 37996. Email: derek.h.alderman@gmail.com. His research and teaching focus on the cultural and historical geographies of the American South, with special attention devoted to sense of place, media representation, memory and heritage, and African American identity politics. He is the founder of RESET (Race, Ethnicity, and Social Equity in Tourism), an initiative that seeks to enhance the role of minorities in the marketing and development of cultural and heritage tourism.

STEFANIE K. BENJAMIN recently completed a Master of Science in Sustainable Tourism from East Carolina University. She is currently a doctoral student in the School of Hotel, Restaurant, and Tourism Management at University of South Carolina in Columbia, South Carolina, 29208.Email: benjamsk@ email.sc .edu. Her research interests include the effects of popular culture and film/television on tourist destinations as well as incorporating social justice and African American belonging into tourism planning and development.

PAIGE P. SCHNEIDER is an Assistant Professor in the Department of Recreation Leisure Studies and Affiliate Faculty in the Center for Sustainable Tourism at East Carolina University in Greenville, NC 27858. Email:

schneiderp@ecu.edu.Her research and teaching interests are consumer behavior and tourism with a special interest in adventure, ecotourism (both supply and demand), and sustainable community-based tourism development. 